Veronica Binda

Bocconi University (Italy)

\title{
A Short History of International Business in Italy: What We Know and How We Know It
}

\begin{abstract}
This article is a voyage through the history of international business in Italy, one which takes contemporary studies and, in particular, studies conducted over time by business historians from the Italian Unification until the present day, into account. After a brief introduction, the first part of the article is devoted to an analysis of the literature, especially focusing on the early studies conducted on foreign capital until World War II, on the investigations done in the second part of the twentieth century, and on the most recent trends and contributions in research. The second part of the article deals, in a stylised way, with a very short summary of the principal information that we have attained on foreign direct investments in the country, with a special focus on international business in Italy before the Great War, in the inter-war years, until the 1980s, and in the most recent decades. Finally, the conclusions indicate the possible main directions for future research in this field.
\end{abstract}

Keywords: Business History; International Business; Italy; Multinationals

\section{Introduction}

On 2 July 1861, a few months after the political unification of the country, Italian politicians were already debating intensively in Parliament. The subject of the debate was the approval of an agreement signed on 12 May which granted the concessions for the construction of a new railway to connect Naples to the Adriatic sea to foreign investors. "The steam engine is more

\footnotetext{
Corresponding author. E-mail: veronica.binda@unibocconi.it

Received 09 May 2016 - Accepted 06 June 2016

This is an Open Access article distributed under the terms of the Creative Commons Attribution-Non-Commercial-No Derivatives License (http://creativecommons.org/licenses/by-nc-nd/4.0/), which permits non-comercial re-use and distribution, provided the original work is properly cited, and is not altered or transformed in any way.
} 
than a material locomotive. It is a moral locomotive, which triples credit, commercial motion, and the wealth of a nation. [...] Railways were at the base of the dynamics which raised the power of England, America, and France", argued one of the main opponents to the law. "Railways, which could be a valid instrument to educate people to associate and work, will be only imported from abroad. It will be an artificial motion, with no roots in our country, and we will act simply as the paying audience, obedient day labourers. The huge industrial and financial operations will be done in Paris, London, Brussels. The carriages which could have come out from our factories in Naples, Ancona, Milan and Genoa will be provided by Talabot's factories, produced in Paris or Marseilles, at a price that suits their needs better. The only honour we will have is that of paying the bill." (Camera dei Deputati, 1861, 1719) Foreign direct investments had been significant players on the scenario of the Italian economy from the very beginning, but, as one might guess from these first sentences, their relationships with local players have been characterised by many ups and downs.

It is well known that foreign investments, in all their different shapes, have represented a relevant agent of economic growth since the second part of the nineteenth century. Scholars have pointed out that knowledge, technology, and capital coming from abroad have all played a very important role in making the industrial take-off possible in several late-comer nations. At the same time, the existence of markets, and/or a labour force, and/or raw materials, outside national borders was often crucial for the growth strategies of the large corporations of the most advanced nations (Jones 2005; Wilkins 1970, 1974; Franko 1976). Italy was not an exception in this sense, and it attracted significant amounts of foreign investments throughout its history. Even though the Italian share of foreign direct investment as a percentage of GDP is quite low today compared to the most advanced European nations - 
17.33 per cent compared to 19.3 for Germany, 25.6 for France, and 56.37 for the United Kingdom (UNCTADSTAT 2016) - Italy was nonetheless a host economy of no small relevance for multinationals, as recent investigations show (Colli 2014). On the other hand, compared to the attention that has been devoted to other kinds of companies, such as stateowned enterprises, large domestically-owned private firms, and, more recently, small- and medium-sized enterprises, multinationals were, by and large, overlooked both by Italian economic and business historians and by contemporary scholars throughout the twentieth century, at least up to quite recent times.

The main aim of this article is to map the existing studies on international business in Italy from a long-term perspective and to summarise the situation, assessing what we actually know about this topic, and how we were able to deduce this knowledge. Following this brief introduction, the second section of the article will present the most important works on international business in Italy and will briefly summarise their focus and research questions as well as their main outcomes. Three broad historical periods of research on international business will be considered, i.e., early studies until World War II, investigations conducted in the second part of the twentieth century, and, finally, recent research. The second part of the article is then devoted to briefly sketching our present knowledge of international business and its dynamics in Italy in the long run. Conclusions and hints for future research close the work.

\section{Investigations into Long Term International Business in Italy: An Overview}

\section{Early Studies of Foreign Capital}

The worries generated by the extensive presence of foreign investors in the railway sector did not inspire significant studies of international business in the country, at least not in the 
nineteenth century. The issue of the "Italianity" of a corporation was discussed to a certain degree and under certain circumstances, and was also used by some businessmen in order to promote their business against foreign investors before the Parliament. Just to provide a significant example, it was in the name of "Italianity" that the Rothschilds were excluded from the construction of a major part of the railways in the South of Italy to the advantage of a group of national investors (Camera dei Deputati 1862). Nevertheless, attention to the presence of foreign investors in the country did not lead to specific studies on the presence of foreign capital in Italy, nor were there any relevant publications on this subject until the beginning of World War I. After all, the crusade against the supposed foreign conquest of the Italian railways was probably only superficial, given the fact that it was soon discovered that the group of "Italian" investors which in the end obtained the concession to build the railways was supported by the Rothschilds' rivals - the French bankers and businessmen, the Péreire brothers. At the same time, foreign investments were also becoming more and more pervasive in several other industries.

No exhaustive, official lists of foreign-controlled companies were systematically compiled in Italy before the second part of the twentieth century, and the quantitative information that we possess until World War II is only partial and quite fragmented. The Ministry of Agriculture, Industry and Commerce compiled a list of foreign-owned companies for fiscal reasons, but this list is incomplete and is available only for the 1890s (Ministero di Agricoltura, Industria e Commercio 1899). Some foreign-controlled companies were included in the yearbook of the Italian Joint-Stock companies, edited by Credito Italiano from 1908 to 1926 and by the Association of Italian Joint-Stock Companies (Associazione fra le società italiane per azioni) from 1928 onwards. Until the year 1928, the yearbook included a section on the "foreign- 
based companies operating in Italy". However, this list is also incomplete, and, moreover, only joint-stock companies with a company capital higher than 1,000,000 Lire (500,000 Lire only in 1914) are included (Credito Italiano, various years).

The best picture of foreign direct investments in Italy and the perception of them can, however, be found in a pamphlet written in 1915 by a very well-known Italian Radical politician (Prime Minister of Italy between 1919 and 1920) and economist, Francesco Saverio Nitti (1915). "The action of foreign capital in Italy has been very relevant for a long time. It tends to become proportionally much less relevant," claimed Nitti in the opening of this book (Nitti 1915, 9). According to his interpretation, some foreign companies were "greedily wanted" (Nitti 1915, 14) and were invited to the country, since the newly born nation of Italy had a severe lack of both capital and the knowledge of "big business" industries just when "big businesses" outside Italy were becoming gigantic. After an overview of the economic features of the main capital exporters in Europe (Great Britain, France, Germany, and Belgium), Nitti explored the variety and characteristics of foreign capital in Italy and pointed out the relevant presence of foreign-owned enterprises in the most strategic industries, at the same time stressing the declining role that non-domestic investors were playing in the country, compared to national players. However, some concerns emerge quite clearly when the statesman claims that "no foreigner should have a dominant role in our finance, in our banks, in our industry." (Nitti 1915, 57).

From the outbreak of the Great War, foreign investments, and especially German-owned ones, gained increasing attention. Several anti-German propaganda books and pamphlets were published. Books and articles significantly entitled Not xenophobia, but autarky (Pantaleoni 1914), Germany conquering Italy (Preziosi 1915), War without blood (Gray 1915a), and The 
German invasion of Italy (Gray 1915b), to provide just some examples, very effectively symbolise the increasing tension and the hostile climate which was brewing particularly against German-owned companies in the country.

The two decades following the end of the Great War are strongly lacking in information about both the extent and the kinds of foreign direct investments in Italy. However, some quite scattered and sporadic quantitative information on foreign companies in Italy can be retrieved in a publication edited by the Ministry of Finance in the mid-1920s (Ministero delle Finanze, 1925-1926) and, indirectly, from foreign sources on specific foreign investors. This is the case of the information provided by the US Department of Commerce of American direct investments in foreign countries (US Department of Commerce 1930). Even though, as will be shown in the second section of this article, foreign companies were strongly present in the country despite the nationalistic rhetoric of the fascist regime especially during the 1930s, contemporary relevant works on international business in Italy in the inter-war years are basically absent. On top of this, a proper analysis of foreign-controlled companies active in Italy based upon sources from the 1920s and 1930s, especially in the years which directly preceded the war, is further complicated by the fact that, in such a hostile context, many foreign companies camouflaged their real identities.

\section{Analyses of International Capital in the Second Half of the Twentieth Century}

Investigations into international business in the country flourished again after the end of World War II. Already in the 1940s, some first estimations were made of both the amount and the distribution of foreign direct investments in Italy. The Constituent Assembly provided a first picture of what had happened during the 1930s, claiming that a relevant drop in the flow of foreign direct investments had occurred (Del Buttero 1946). The Italian General 
Confederation of Labour trade union (CGIL) also commissioned some research in order to assess the relevance of foreign capital in Italy after the war (CGIL 1948, 1949). However, the first real attempt to set up a database of the presence of foreign-controlled companies in Italy dates back to the early 1960s and was conducted by Walter Giorgio Scott (Scott 1960). The database includes foreign-controlled joint-stock companies that held a share of capital of at least 50 million Italian Lire in 1958. After an overview of the Italian legislation on foreign investments, Scott analysed the population of multinationals according to their geographical origin and the industries in which they were active, focusing, in particular, on mining, metallurgical industries, mechanical engineering, oil, chemical, textile, food, glass and pottery industries, commercial, financial and insurance services, and other various industries. Despite some limitations and minor mistakes of attribution, Scott's database, made up by almost 500 enterprises which were, either in part or completely, under foreign control, provides relevant information for that specific year and paved the way to the set-up of other quantitative databases, which were built in the following decades. In the late 1960s, a research group published a new database which included 1,269 firms, in which foreign capital was equal or higher than local capital or, in any case, of a relevant amount, considering both joint-stock companies and limited liability enterprises in Italy in 1966 (SORIS 1968). In this case, too, foreign multinationals were classified according to their industry, and a sectoral analysis was included in the work. The next database was built by Carlo Monotti in the 1970s, who mapped the main firms and groups in Italy, separately considering "state-owned", "Italian private-owned", and "foreign-controlled" groups (Monotti 1975). Finally, since 1984, a database named "Reprint" has provided extensive information on foreign-controlled companies in the country. This database, made up of joint-stock companies and limited 
liability firms, was created by Sergio Mariotti and Marco Mutinelli, and was published yearly until 2006, and every other year after that, with the title Italia Multinazionale (Ricerche e Progetti, various years).

The construction of databases of foreign-controlled companies in Italy made important progress during the second part of the century, even though a comprehensive dataset built on a long-term homogeneous source was still lacking in the early 2000s. Notwithstanding this, the set-up of the databases represented only a part of the efforts made by scholars in studying international business in Italy.

Before presenting the main contributions provided by business historians in this sense, I would like to highlight the emergence, during the second part of the twentieth century, of several studies from different disciplines, such as law, economics, accounting, management, and so on, which, for the first time, had to consider the topic of foreign direct investments in Italy actively. Just to provide some examples, accompanying - and in the light of the promulgation of - new laws by the Italian government to regulate and attract foreign capital, scholars of law started to produce and public research in this field. The work published by Salvatore Baeli, which aimed to re-construct and describe the whole new regime for foreign investments in the country, represents one of the first steps here (Baeli 1957). Economists started to enquire into the contribution of foreign private investment to the solution of Italy's main economic troubles (for example, Mini 1968). The economic and financial performances of multinational firms in the country became a new subject of research for accounting scholars, especially in those geographic areas in which they were expected to contribute more to the economic growth of the country, such as the Southern part, the so-called Mezzogiorno (for example, Venturelli, Milone and Pastore 1979). The strategies and organisational forms of 
foreign corporations started to be more and more frequently analysed and compared to those of Italian companies by management scholars with the aim of understanding the reasons of their success and teaching them in class discussions (for example, Chiadò-Fiorio et al. 1973; Pavan 1976). The transformation which occurred in the literature of these disciplines with regard to international business over more than fifty years is huge, and it would be an interesting topic to be considered. Unfortunately, it is beyond the realms of this work to investigate these dynamics in all these fields.

Focusing on the progress made by business historians into international business in these decades, some topics were especially addressed. Simplifying a great deal, the existing studies conducted in the second part of the twentieth century can be catalogued in two broad categories: those which focused on specific company case studies, and those which investigated the dynamics of foreign direct investments in Italy based upon their geographical origin. The analysis of US capital in Italy is an important sub-category of the latter group of studies.

Among the most famous studies of a company history, it is worth mentioning the works by Peter Hertner on Tubi Mannesmann both before and during the first years of the Great War, and on Officine Lombarde Apparecchi di Precisione in the inter-war years (Hertner 1978; Hertner 1986), by Luciano Segreto on Vickers until the outbreak of World War II (Segreto 1985), by Francesca Bova on Cucirini Cantoni Coats from 1912 to 1929 (Bova 1987); and by Stefania Licini on Tecnomasio Italiano Brown Boveri from its origins up to the 1930s (Licini 1989-1990).

As far as the investigations of foreign capital catalogued according to geographical origin are concerned, the countries which have received most attention, also according to their 
significant importance as foreign investors in Italy, are Belgium (Dumoulin 1989; Dumoulin 1990), France (Gille 1959; Bouvier 1961; Gille 1968), Germany (Hertner 1981, 1984; von Oswald 1994), and Switzerland (Segreto 1987). Peter Hertner also worked on a special kind of foreign direct investment in Italy, namely, free-standing companies, between 1883 and 1912 (Hertner 1998). American capital in Italy deserves a separate mention in this work, given the great attention which has been devoted to this topic both by Italian and foreign scholars. US direct investment in the Italian manufacturing sector in the period preceding World War II has been especially investigated by Mira Wilkins and Francesca Bova (Wilkins 1970; Bova 1995). As far as the post-war period is concerned, many studies, conducted both by contemporary scholars and by authors who wrote at a later stage, worked extensively to assess the features and the impact of the Marshall Plan in Italy (for example, CIR 1952; Harper 1986; Toniolo 1983; D'Attorre 1985a, 1985b). Luciano Segreto, on the other hand, is the scholar who has most extensively dealt with American capital in the country since the end of World War II and during the decades of the Italian "Economic Miracle", the 1950s and 1960s (Segreto 1995, 1996).

\section{Recent Research on Multinationals: Scholars and Topics}

What is contemporary economics and management literature on international business currently discussing in Italy? Looking at the main topics of interest in the last fifteen years, it is possible to find an overlapping of "old" and "new" themes. The declining attractiveness of the country as a host economy for multinationals provided an important incentive for scholars to investigate the role of the institutional context in making Italy attractive or not for foreign direct investments (De Santis and Vicarelli 2001; Basile, Benfratello and Castellani 2005; Basile, Castellani and Zanfei 2004). Special attention in this sense has also been given to the 
political context of the country (Mudambi and Navarra 2003a, 2003b). The issue of the locational choices and geographical distribution of multinationals in Italy is still important in the literature (Pazienza and Vecchione 2009), and we can find investigations both of the Southern part of the country (Basile and Mantuano 2008) and of the Northern part, especially Lombardy (Onida 2007). At the same time, foreign companies are also analysed according to their geographical origin. Multinationals from emerging countries have been studied by Sergio Mariotti and Mauro Mutinelli (Mariotti and Mutinelli 2008), while foreign investments from China have been investigated by Carlo Pietrobelli, Roberta Rabellotti, and Marco Sanfilippo (Pietrobelli, Rabelotti and Sanfilippo 2013). In this respect, Giuseppe Tardivo and Rui Dias worked on the (temporary versus permanent) effects of foreign direct investments in Italy by also taking their country of origin into account (Tardivo and Dias 2003). The entry modes of multinationals have been investigated according to different location choices (Basile 2004), and with a special focus on greenfield investments (Mariotti and Mutinelli 2014), while the performances of these companies in Italy has been assessed in a study on the relationship between multinational ownership and survival (Ferragina, Pittiglio and Reganati 2014), and by analysing performance differences both across and within foreign-owned firms and domestic multinationals in Italy (Grasseni 2010). One of the topics which most attracted the attention of scholars is currently the technological contribution that capital and technology coming from abroad can provide for the national environment. Filippo Reganati and Edgardo Sica studied the horizontal and vertical spillovers from FDI in Italy (Reganati and Sica 2007), while other investigations focused on the determinants of technology transfer between parent firms and their international affiliates, and of knowledge spillovers from these affiliates to Italian firms (Driffield, Love and Menghinello 2010) as well as on the relationship between 
multinationals and high technology industries in Italy (Mariotti and Mutinelli 2006). Finally, foreign corporations have been observed in the specific context which characterised the Italian economy at the turn of the century, between industrial districts (Bronzini 2004; Mariotti and Mutinelli 2003; Mariotti and Mutinelli 2004) and the privatisation of big businesses (Affinito, De Cecco and Dringoli 2000).

With the arrival of the new millennium, international business history has entered a new phase and seen a renewed interest. Many studies have been conducted in Italy during this period. It is possible to catalogue the most recent contributions in three main areas. First, we have new empirical evidence on company cases. Marco Bertilorenzi, for instance, described the strategy adopted by Saint Gobain in Italy between 1887 and 1939 (Bertilorenzi 2006) and worked on the history of aluminium in Italy from 1917 to 1943 (Bertilorenzi 2008). Laura Solimene wrote a history of SIV and the flat glass industry (Solimene 2000), while Pier Angelo Toninelli focused on Ford's unsuccessful attempt to build a solid base of operations in the country (Toninelli 2009). Monika Poettinger provided more empirical evidence working on the history of foreign entrepreneurs in Italy, with a special focus on German entrepreneurs in Lombardy in the early nineteenth century (Poettinger 2007).

A second sign of the renewed vitality of the history of international business in the country is given by the efforts put into gathering more quantitative information and setting up new datasets on international business. Particularly relevant in this sense is the work done by Andrea Colli to build a new and more comprehensive database of multinationals in Italy, which focuses on the 100 largest companies under foreign control in eight benchmark years during the twentieth century $(1913,1921,1927,1936,1952,1960,1972)$. In addition to building the database, Andrea Colli has been particularly committed in recent years to 
mapping and analysing the features and dynamics of these populations of foreign multinationals in Italy (see, for instance, Colli 2010).

Last, but not least, in the most recent years, business historians have improved their efforts to deal with unexplored topics and to tackle some specific and relevant issues. Andrea Colli has worked on the role played by foreign direct investments in the process of Italian economic growth and the entry modes of multinationals (Colli 2014). Veronica Binda has analysed the strategies and organisational structures adopted by the largest multinationals in the country, comparing them with what national companies did in the second part of the twentieth century (Binda 2013). Recent research by Veronica Binda and Mario Perugini has started to focus on the specific dynamics of the interaction which occurred in joint-ventures between local and foreign partners in some specific industries (Binda and Perugini 2016).

The following section will present a very brief and simplified summary of the main evidence which business historians have been able to provide until now on long-term international business in Italy.

\section{International Business in Italy: What we Know}

The Kick-off: Multinationals as a "Substitutive Factor" in a Late-comer Nation?

The existing literature allows us to sketch some of the basic features of foreign direct investments in Italy since the late nineteenth century. The picture shown on the eve of World War I, after the economic expansion experienced by the country during the so-called "Giolittian era" (1901-1914), includes multinationals as important protagonists. According to the mainstream literature, even though it is not possible to speak of a "big spurt" yet, it was in this historical period that the real industrialisation process started in the country. Industries from the First, and, even more, from the Second Industrial Revolution, had been growing at 
unprecedented rates since the beginning of the 1890s. A few large private companies were created to exploit opportunities in new sectors, such as Falck in steel, Fiat in the automobile industry, and Pirelli in rubber. The establishment of two institutions somewhat analogous to the German universal banks, to wit, Banca Commerciale and Credito Italiano, marked a stark departure from the usual practices of the Italian banking system. At the same time, government involvement in the domestic economy was increasing, as the pursuing of active policies to industrialise the Southern part of the country proves (Romeo 1988; Cafagna 1989; Zamagni 1990; Amatori and Colli 1999). According to Andrea Colli, within this framework, "multinational firms played an important role acting, in several cases, exactly as Gerschenkronian substitutes for weak, or even absent, domestic entrepreneurship" (Colli $2014,304)$.

During the first wave of globalisation, the Italian government was a fairly active actor in international economic relations, especially from the 1880 s, when new protectionist policies were adopted in the agricultural sector and successively extended to manufacturing. But, in line with what was happening abroad, no law restrictions hindered or prohibited the entrance of foreign capital. Nor were there any particular incentives. In the context of a latecomer country which was increasingly closed to international trade, but not to international investments, foreign investors were attracted, and entered in a similar manner to what happened in other promising industrialising nations (see, for instance, Jones 2008).

Scholars who have dealt with foreign direct investments in Italy during this period have basically agreed that foreign controlled firms were quite common in the country. According to Francesco Saverio Nitti, foreign direct investments in Italy were already pervasive before World War I in most of the "strategic industries", such as mechanics, steel, energy, utilities, 
and transport (Nitti 1915). Peter Hertner detected an impressively high presence of German investments, especially in finance, services, transportation, and manufacturing (Hertner 1984). Vera Zamagni has also found a pervasive presence particularly of German and Swiss companies in the capital- and technology-intensive industries (Zamagni 1978). Mira Wilkins provided information of some of the subsidiaries of US multinationals in Italy in the same period (Wilkins 1970), and there is also evidence of British, Belgian, and French investments (Bova 1987, 1995; Dumoulin, 1989, 1990; Gille, 1959, 1968). The evidence provided by Andrea Colli's database for the year 1913 can be summarised in three main points: (1) a large number of industries were affected by the presence of foreign capital; (2) the concentration of foreign capital privileged capital- and technology-intensive industries; and (3) as far as the distribution of the foreign-controlled companies by the home country is concerned, Belgium and France accounted for almost 44 per cent of the total investments of the sample, and they were focused, above all, on utilities and public transportation; Switzerland accounted for about 20 per cent, and invested in particular in utilities (primarily electricity), but also in the textile industry; German capital accounted for about 17 per cent and principally focused on electricity, chemicals, transportation, and mechanical engineering (Colli 2010).

\section{A Love-hate Relationship: Histories of International Business in the Inter-war Years}

"Industrial mobilisation" pushed the Italian industrialisation process onto a "road with no return" during the Great War, when industries such as steel, engineering, chemicals, and shipbuilding underwent rapid expansion. Despite the post-war economic crisis and the Great Depression of the 1930s, Italian industry continued to grow in the inter-war years. The 1920 s were rather positive for the Italian economy (Toniolo 2013, 18-19). Industrial production increased in almost every sector, especially in the chemical industry. But things started to 
worsen during the 1930s, due to both domestic and international dynamics. In 1933, a huge operation to rescue the main Italian universal banks brought about the creation of the stateowned holding Istituto di Ricostruzione Industriale (IRI).

In the context of the general turmoil and the backlash against globalisation that basically hit the whole world at the time, the attitude towards international trade and investment also changed in Fascist Italy during the 1920s, and especially during the 1930s. This decade was characterised by the imposition of greater trade barriers and more trade restrictions, which were progressively tightened until they reached forms of "autarky" (Toniolo 1980). As far as the laws on foreign investments were concerned, several decrees were issued in Italy during the 1920s. They sought to attract capital from abroad, mainly by creating fiscal advantages (see, for instance, the Royal Decree Law of 16 December 1922, no. 1634 and the Royal Decree Law of 11 September 1925, no. 1925). At the same time, on the other hand, these decrees made it increasingly compulsory to obtain government authorisation in order to invest in Italy (see the Royal Decree Law of 10 December 1925, no. 2162). With the Royal DecreeLaw of 5 January 1928, every foreign operation of every kind and duration in Italy had to be previously authorised by the government. Authorisations were limited to only those foreign loans that were intended to pursue "productive activities". According to this last law, in order to obtain authorisation "to have credit from abroad", it was necessary to make an application that cited the reason for the loan, the terms that had been established, and all the other relevant information. Moreover, the government could make constant controls to check that the capital was really used in the "productive activity" mentioned in the application (Scott 1960). No new legislation was enacted with regard to foreign investment in the 1930s. During the war, all 
companies that were controlled by the citizens of Italy's enemies - or in which they had more than 50 per cent of the share capital - were confiscated (Royal Decree Law of 28 June 1940). If we look at the concrete activity of multinational companies during the inter-war period, we can note that an important discontinuity in the activity of multinationals in Italy had occurred since World War I, when important German and Austrian companies in mechanics, metallurgy, and utilities were "Italianised". Notwithstanding this, most of the multinationals from other nations continued to operate in Italy during the 1920s. According to the big picture provided by the Constituent Assembly right after World War II, a general slowdown in the Italian inward foreign direct-investment flow had taken place in the inter-war period (Del Buttero 1946). According to Andrea Colli's database, the paradigm of foreign direct investments changed in this period, shifting from utilities, transportation and public services in general, to a stronger focus on manufacturing, technology and capital-intensive industries. As far as the nationality of foreign investors is concerned, apart from the already mentioned cases of Austria and Germany, only Belgium showed a persistent decline in representation. Switzerland and France remained quite constant and the United States' investment declined immediately after the 1929 crisis but re-started in the decade preceding World War II (Colli 2010).

\section{"Re-opening the Doors": International Business from the End of World War II until the 1980s}

The real Italian take-off occurred after World War II. During the 1950s and 1960s, the Gross National Product grew at a rate of almost 6 per cent (Zamagni 1990, 423-424). "Light sectors", such as textiles, shoe manufacturing, and household furnishings moved from being run by able craftsmen to "true industries", while the industrial structure of the country was becoming stronger in basic sectors, such as oil, steel, and durable consumer goods. During 
this period, albeit with some idiosyncrasies, the Fordist model spread in the country, also taking advantage of the abundant Italian labour force and of the exploitation of economies of scale made possible by an expanding domestic market. Among the main discontinuities with the previous period, it is worth mentioning the new and more pervasive role taken by stateowned companies in Italy. On the one hand, state-owned companies became an instrument for offsetting the effects of the liberalisation of trade dictated by the recently founded European Economic Community, by providing more specific import-substitution and export-promoting investment. On the other, they started to achieve aims such as undertaking long-term, highrisk projects that private enterprise was unwilling to undertake, the maintenance of effective competition in oligopolistic sectors not exposed to foreign competition; and, finally, coping with the presence of multinational enterprises in the country (Amatori 2013).

Drawing inspiration by an article written by Luciano Segreto (Segreto 1995) it is possible to claim that "doors were re-opened", and that multinationals were welcomed again. The legal efforts to encourage foreign investment resulted in two major laws. The first one, approved on 2 March 1948, aimed to provide foreign investors who were extremely suspicious and distrustful after the war with at least some legal certainties. However, this law was not a sufficiently strong incentive for foreign capital to enter Italy, also because no more than 6 per cent of the profits could be repatriated. The second law, approved on 7 February 1956, was the first one that distinguished among foreign direct investments, portfolio investments and loans. As far as the first kind of investment was concerned, the law established that investments which were aimed at "productive activities" - i.e., the production of goods or services - could repatriate their dividends and profits without any restrictions. 
According to the evidence provided by Andrea Colli's database in the benchmark years 1952 and 1960, during the "miracle", the United States established itself as the most important investor, while both France and Switzerland reduced their presence slightly. During these decades, there were new foreign investments in Italy, with a quite heterogeneous industrial destination. Although there was little change in the case of food, beverages and non-metallicproducts, in other cases, such as the chemical sector, machine tools and equipment, and electric machinery, the presence of foreign capital grew impressively. The picture at the beginning of the 1970s showed both continuities and differences. The United States remained the most important investor, followed by Switzerland and France. Chemicals and machinery remained strongly characterised by the foreign presence. In the chemical industry, the presence of foreign companies was confirmed both at the top level, as well as in small- and medium-sized companies. In machinery, foreign capital remained important in machine tools, machines for special purposes, and especially in electrical machinery (Colli 2010, 2014). Foreign companies were, moreover, heavily involved in high-technology projects together with state-owned firms. The Italian government was, in fact, using IRI to invest in sophisticated sectors, such as telephone equipment, electronics, satellite components, and passenger aircraft, frequently developing joint-ventures with leading foreign companies as a means of securing the required technology (Colli 2014). These dynamics are reflected in the composition of the rankings of the largest companies in Italy during the late 1960s and early 1970s. The population of state-owned companies and foreign enterprises among the 100 largest firms in the country grew considerably while, at the same time, there was a sharp drop in the presence of independent Italian firms (Binda 2013). 


\section{Current Dynamics}

An analysis of the contemporary situation goes beyond the aims of this brief summary. It is well-known that the Italian process of catching-up ended in the early 1990s. Despite the pursuance of privatisation and liberalisation policies that occurred during the 1990s, which, according to policy-makers, should have helped the Italian economy to improve, the country performance has been very weak since that time, and a slow recovery around the middle of the 2000s was soon stopped by the world economic crisis of 2007. Much has been written about this. According to the economic historian Gianni Toniolo, Italy's loss of growth capability can be explained - at least in part - by considering "(1) a decrease in size, scope and productivity of the large firms, (2) an increase of the debt-to-GDP ratio over and above the supposedly "critical" threshold of 90 per cent, and (3) a shift from under evaluation to over evaluation of the real exchange rate of the currency." (Toniolo 2013, 29)

The current Italian economic conditions and the opportunities for recovery are, of course, a subject of intense debate. Returning to the main purpose of this study, what is certain is that, since the early 1980s, Italy became a less attractive host economy for foreign investors (Onida, Mariotti and Piscitello 2003). The poor economic performance of the country and the great opportunities provided by the emerging countries in the decades of the "Second Global Economy" contribute, to a large extent, to explain Italy's declining capacity to attract international investment. According to Mariotti and Mutinelli, a further "alarming decline" of foreign direct investments in the country took place during the period between the years 20002008 (Mariotti and Mutinelli 2010). Even in the context of a stagnating Europe, Italy is less able to attract foreign multinationals than its European counterparts, such as France, Germany, Spain and Great Britain, as mentioned in the introduction to this article. 
According to the publication Italia Multinazionale 2014, which, every two years, maps the situation of Italy with regard to the stock of inward and outward foreign direct investments, the gap between Italy and the other European nations further increased during and after the economic crisis. According to the report, foreign direct investments have reduced their importance especially in the manufacturing sector, with the relevant exception of mechanical instruments, "made in Italy"-related industries, and a few other areas. While stressing the fact that greenfield investments are a minor proportion of foreign direct investments compared to brownfield investments, the work also shows that while the investments coming from the main investors in the country, such as North America and Europe, are stagnating or declining, the percentage of investments coming from new areas, such as China, India, Russia, and other, especially Asian, countries, is rising at a remarkable rate (Ricerche e Progetti 2014).

\section{Conclusions: Looking Ahead}

Slightly more than a hundred years have past since Francesco Saverio Nitti wrote the first attempt to quantify the presence of foreign companies in Italy in 1915, endeavouring to establish their origin, sectoral distribution and impact on the eve of Italy's entry into World War I, showing his concerns about the country's dangerous dependence on foreign countries. Many things have changed since then: both Italian and foreign scholars have worked on mapping and interpreting foreign direct investments in the country, and some databases, investigations based upon the geographical origin of foreign investors, and company cases have made it possible for us to start to understand the quantitative presence of multinationals in the country, the distribution by sector and the geographical origin of the largest of them throughout the twentieth century, and to assess, in some cases, their behaviour and relationship with the local context. Having said this, it should be stressed that the information 
that we actually have on long-term international business in Italy is still quite scarce and patchy, and important dynamics remain, to a large degree, unexplored.

Improving our knowledge in terms of the "quantification" of foreign direct investments in Italy since the Unification of the country (1861) sounds like a very valuable but tough task, given the scarce amount of statistical information that we have on this topic especially in some historical periods. On the other hand, it is feasible and recommended to assess and understand the dynamics of international business in Italy better. Out of the many possible directions that research could take in the next years, I would like to suggest three alternative and, at the same time, complementary, broad directions to follow.

The first way to improve our knowledge on this topic is to focus more on the economic dynamics which are strictly related to international business in Italy as a host country, with a problem-oriented approach. Many studies, both currently as well as in the past, have enquired into the impact of foreign direct investments in Italy. Some of these investigations, in a sense, also shaped the economic policies pursued by the government in order to attract or reject foreign direct investments. But, in order to properly assess the relevance of the impact of multinationals in Italy we should investigate some issues in greater depth. With the exception of a few specific case studies, we are still basically ignorant of the extent to which multinational companies had an impact in transferring knowledge. The search for a transfer of knowledge, in terms of technology, know-how, organisational capabilities, and so on and so forth, is probably one of the main reasons which urge governments today, as in the past, to try to attract multinationals. On the other hand, it is also quite well-known that multinational companies do not wish to transfer knowledge, and that they try to avoid the transfer of knowledge to local potential "competitors" whenever they can. The same, of course, 
happened in the past. The extent to which foreign knowledge was incorporated into the Italian industrial system in the long run is still largely to be investigated, and we are basically ignorant of both the amount and the relevance of the spillovers coming from multinational firms to different industries over time, as well as their impact in fostering the development of local entrepreneurial talent. Following up on this point, we are not able to answer exhaustively and satisfactorily another classic question on foreign direct investment yet, i.e., the impact of multinationals on the local environment in terms of hindering or fostering the emergence of local companies in this field. Did multinationals help Italy to catch-up by favouring the improvement of the knowledge and capabilities held by local companies, or did they simply make it impossible for the country to develop companies in those sectors in which stronger foreign multinationals were already present and carefully avoided sharing knowledge, thereby causing the country's long-term dependence on foreign multinationals? Apart from the pioneering attempt made by Andrea Colli (2014), no reliable attempts to deal with such a major topic have been made to date. Studying in greater detail the entry and operation modes of multinationals in Italy would greatly help us to answer these questions, but we still know very little about the entry modes of multinationals or their way of interacting with the local economic system and with the existing native companies. As has already been mentioned, we are still in the early stages of understanding these phenomena, and, to date, we have probably only analysed the "tip of the iceberg", by focusing exclusively on only the very largest corporations (Colli 2014) and on the cases of some specific industries (Binda and Perugini 2016).

Secondly, but no less important, we do not have a fully convincing "big picture" on relevant topics such as the political influence that foreign direct investment had on the Italian 
government or the social attitudes towards foreign direct investment in the long run. Although, in some specific cases, studies have stressed the lobbying activities both by foreign and local companies in order to defend their interests at national level, a big comparative analysis of the outcomes of these efforts is still lacking. In addition, apart from a few studies dealing with specific periods and companies, it has, to date, been difficult to identify how foreign multinationals were perceived by local society, and how these perceptions changed over time. According to a challenging study by the sociologist Mauro Guillén (2001), the topic of multinationals tends to be more divisive in newly-industrialising countries than in developed ones. According to Guillén, multinationals in the former group of countries can be catalogued as having one of four potential images: "partners", "necessary evils", "arm'slength collaborators", or "villains". Even if one takes its significant regional differences into account, Italy was still a developing area at the end of the nineteenth century and for part of the twentieth century. While it would be very interesting to understand the perception that Italian society, in its various forms, had of the multinationals, and how this changed over time, no broader investigations into these topics have so far been conducted on a large comparative scale, with very few exceptions (see, for instance, Pells 1997; De Grazia 2005; Bonin and de Goey 2009).

Last, but not least, I think that a stronger effort in international comparisons would help Italian scholars to tackle their questions on the economic, political and social impact of foreign multinationals in the country better. To this purpose, it might be particularly interesting to look at Southern Europe, and this special issue is particularly appropriate and timely in this sense. Even though Italy, Spain, Portugal, and Greece were characterised by significant differences, it is possible to identify some features of their economic development 
that made these nations similar to each other and quite different from other European nations. The strong intervention of the state in company ownership, creation, and protection, the fundamental role played by a small number of very big and diversified business groups, the importance of small- and medium-sized private corporations, and, last, but not least, the controversial relationship with foreign capital and know-how, which, in some phases, was almost desperately desired, and, at other times, completely rejected, were common features of these Southern European countries (Binda 2013). To a limited extent, these nations also share another characteristic: the economic weakness that nowadays has earned them the insulting acronym of "PIIGS", which also includes Ireland. But notwithstanding these common features, and the need to delve deeper into the dynamics that guided the nineteenth and twentieth century development of these nations, an effective effort in constructing the "big picture" that analyses and understands the role and the behaviour of multinational corporations in the long run in Southern Europe is still missing.

\section{References}

Affinito, Massimiliano, Marcello De Cecco, and Angelo Dringoli. 2000. Le privatizzazioni nell'industria manifatturiera italiana. Rome: Donzelli.

Amatori, Franco, and Andrea Colli. 1999. Impresa e industria in Italia dall'Unità ad oggi. Venice: Marsilio.

Amatori, Franco, ed. 2013. Storia dell'IRI, Vol.2. Il "miracolo" economico e il ruolo dell'IRI. RomeBari: Laterza.

Baeli, Salvatore. 1957. Investimenti e finanziamenti esteri in Italia. Investimenti diretti e di portafoglio. I prestiti privati esteri. Rome: Guido Pastena.

Basile, Roberto. 2004. "Acquisition versus greenfield investment: the location of foreign manufacturers in Italy." Regional Science \& Urban Economics 34 (1): 3-25. 
Basile, Roberto, Davide Castellani, and Antonello Zanfei. 2004. "La localizzazione delle imprese multinazionali in Europa: il ruolo delle politiche dell'UE e le peculiarità dell'Italia." L'Industria 3: $571-596$

Basile, Roberto, Luigi Benfratello, and Davide Castellani. 2005. "Attracting foreign direct investments in Europe: Are Italian regions doomed?" Rivista di politica economica 1 (1): 319-354.

Basile, Roberto, and Marianna Mantuano. 2008. "L'attrazione di Investimenti Diretti Esteri in Italia e nel Mezzogiorno: Il ruolo delle politiche nazionali e regionali." L'Industria 29 (4): 623-642.

Bertilorenzi, Marco. 2006. "La méthode Saint-Gobain: Strategia di un'impresa multinazionale in Italia, 1887-1939.” M.Sc. diss., University of Florence.

Bertilorenzi, Marco. 2008. "The Italian Aluminium Industry: Cartels, Multinationals and the Autarkic Phase, 1917-1943." Cahiers D'Histoire de l'Aluminium 41: 42-71.

Binda, Veronica. 2013. The Dynamics of Big Business: Structure, Strategy, and Impact in Italy and Spain. New York: Routledge.

Binda, Veronica, and Mario Perugini. 2016. "Nella buona e nella cattiva sorte? Le joint-venture tra multinazionali straniere e imprese locali in Italia in una prospettiva di lungo periodo." In "Atti SISE".

Bonin, Hubert, and Ferry De Goey, eds. 2009. American firms in Europe (1880-1980). Strategy, Identity, Perception and Performance. Geneve: Droz.

Bouvier Jean. 1961. "Les interventions bancaires françaises dans quelques grandes affaires financières de l’Unité italienne." Annali dell'Istituto G. Feltrinelli IV: 224-233.

Bova, Francesca. 1987. "L'evoluzione di una grande azienda cotoniera: la Cucirini Cantoni Coats dal 1912 al 1939." Annali di Storia dell'Impresa 3: 323-68.

Bova, Francesca. 1995. "American direct investment in the Italian manufacturing sector, 1900-1940." Business and Economic History 24 (1): 218-230.

Bronzini, Raffaello. 2004. Distretti Industriali, economie di agglomerazione e investimenti esteri in Italia, in Economie locali, modelli di agglomerazione e aperture internazionale. Rome: Bank of Italy.

Cafagna, Luciano. 1989. Dualismo e sviluppo nella storia d'Italia. Venice: Marsilio.

Camera dei Deputati. July 2nd, 1861. Atti del Parlamento Italiano - Discussioni della Camera dei Deputati, VIII Legislatura - Sessione 1861 (18/02/1861 - 23/07/1861), Volume (sn) $1^{\circ}$ periodo dal 27/05/1861 al 23/07/1861 N.D.R., 1707-1738. Turin.

Camera dei Deputati. July 31st, 1862. Atti del Parlamento Italiano - Discussioni della Camera dei Deputati, VIII Legislatura - Sessione 1861 - 1862 (12/07/1862 - 01/08/1862), Volume (VI) XII della Sessione $3^{\circ}$ periodo dal 12/07/1862 al 01/08/1862. Turin. 
CGIL. 1948. Tendenze monopolistiche dell'industria italiana. Rome.

CGIL. 1949. Struttura dei monopoli industriali in Italia. Rome.

Chiadò-Fiorio, Elena, Donatella Chiesa, Franca M. Tubini, and Piergiorgio Re. 1973. Le multinazionali nella esperienza italiana. Turin: Litografia Artigiana M.\&S.

CIR. 1952. The development of Italy's Economic System within the framework of European Recovery and Cooperation. Rome.

Colli, Andrea. 2010. "Foreign enterprises (1913-72)." In Forms of Enterprise in 20th Century Italy. Boundaries, Structures and Strategies, edited by Andrea Colli, and Michelangelo Vasta, 87-111. Cheltenham: Edward Elgar Publishing.

Colli, Andrea. 2014. "Multinationals and Economic Development in Italy during the 20th century." Business History Review 88: 303-327.

Credito Italiano (Associazione fra le società italiane per azioni since 1928). Various years. Società italiane per azioni. Notizie statistiche. Milan and Rome.

D'Attorre, Pier Paolo. 1985a. “Anche noi possiamo essere prosperi. Aiuti ERP e politiche della produttività negli anni Cinquanta." Quaderni Storici 58: 55-93.

D’Attorre, Pier Paolo. 1985b. "Il Piano Marshall: politica, economia, relazioni internazionali nella ricostruzione italiana." Passato e Presente 7: 31-63.

De Grazia, Victoria, 2005. Irresistible Empire: America's Advance through Twentieth-Century Europe. Cambridge: Harvard University Press.

Del Buttero, Anna. 1946. Il capitale estero nell'industria italiana. Rome: Ministero per la Costituente, Rapporto della Commissione Economica, II, Industria, I, vol. 2: 93-116.

De Santis, Roberta, and Claudio Vicarelli. 2001. "Fattori di attrazione degli investimenti diretti esteri nell'Unione Europea: il ruolo dl contesto istituzionale e la competitività dell'Italia." Rivista di Politica Economica 91 (3): 3-32.

Driffield, Nigel, James H. Love, and Stefano Menghinello. 2010. "The Multinational Enterprise as a Source of International Knowledge Flows: Direct Evidence from Italy". Journal of International Business Studies 41 (2): 350-359.

Dumoulin, Michel, ed. 1989. Presences belges dans le monde a l'aube du XXe siecle. Louvain: Academia.

Dumoulin, Michel. 1990. Les relations économiques italo-belges (1861-1914). Brussels: Academie Royale De Belgique.

Ferragina, Anna Maria, Rosanna Pittiglio, and Filippo Reganati. 2014. "Does multinational ownership affect firm survival in Italy?" Journal of Business Economics \& Management 15 (2): 335-355. 
Franko, Lawrence. 1976. The European Multinationals. A Renewed Challenge to American and UK Multinationals. New York: Harper and Row.

Gille, Bertrand. 1959. "Le capitaux français au Piémont (1849-1959)" In Histoire des entreprises Vol. 3, edited by Bertrand Gille. Paris: Éditions de l'École des hautes études en sciences sociales.

Gille, Bertrand. 1968. Les investissement français en Italie (1815-1914). Turin: Ilte.

Grasseni, Mara. 2010. "Domestic Multinationals and Foreign-Owned Firms in Italy: Evidence from Quantile Regression.” European Journal of Comparative Economics 7 (1): 61-86.

Gray, Ezio Maria. 1915a. Guerra senza sangue. Florence: R. Bemporad \& Figlio.

Gray, Ezio Maria. 1915b. L'invasione tedesca in Italia (professori, commercianti, spie). Florence: R. Bemporad \& Figlio.

Guillén, Mauro. 2001. The limits of convergence. Globalization and organizational change in Argentina, South Korea, and Spain. Princeton, NJ: Princeton University Press.

Harper John Lamberton. 1986. America and the reconstruction of Italy, 1945-1948. Cambridge: Cambridge University Press.

Hertner, Peter. 1978. 'La società 'Tubi Mannesmann' a Dalmine. Un esempio di investimento internazionale (1906-1917)" Ricerche Storiche VIII: 105-124.

Hertner, Peter. 1981. "Capitale straniero, banche miste e sviluppo industriale in Italia." In L'industrializzazione in Italia (1861-1900), edited by Giorgio Mori, 247-271. Bologna: Il Mulino.

Hertner, Peter. 1984. Il capitale tedesco in Italia dall'Unità alla prima guerra mondiale. Bologna: Il Mulino.

Hertner, Peter. 1986. "Un investimento tedesco in Lombardia tra le due guerre mondiali: le Officine lombarde apparecchi di precisione." Storia in Lombardia 5 (1): 7-67.

Hertner, Peter. 1998. "Free standing companies in Italy, 1883-1912." In The Free-standing Company in the World Economy, edited by Mira Wilkins and Harm Schroeter, 151-160. Oxford: Oxford University Press.

Jones, Geoffrey. 2005. Multinationals and global capitalism from the Nineteenth to the Twenty-first century. Oxford: Oxford University Press.

Jones, Geoffrey. 2008. "Globalization". In The Oxford Handbook of Business History, edited by Geoffrey Jones, and Jonathan Zeitlin. New York: Oxford University Press.

Licini, Stefania. 1989-1990. "Ercole Marelli e Tecnomasio italiano dalle origini agli anni Trenta: Un tentativo di Comparazione." Annali di Storia dell'Impresa 5 (6): 299-321.

Mariotti, Sergio, and Marco Mutinelli. 2003. "L'internazionalizzazione passiva dei distretti italiani." Economia e Politica Industriale 199: 7-19. 
Mariotti, Sergio, and Marco Mutinelli. 2004. "L'internazionalizzazione attiva dei distretti italiani." Economia e Politica Industriale 123: 32-41.

Mariotti, Sergio, and Marco Mutinelli. 2006. "Imprese multinazionali e alta tecnologia in Italia." Economia e Politica Industriale 33 (3): 143-157.

Mariotti, Sergio, and Marco Mutinelli. 2008. "Le multinazionali dei paesi emergenti in Italia." Economia e Politica Industriale 35 (3): 181-187.

Mariotti, Sergio, and Marco Mutinelli. 2010. "Investimenti diretti esteri in Italia: Un preoccupante declino." Economia e Politica Industriale 37 (1): 119-29.

Mariotti, Sergio, and Marco Mutinelli. 2014. "Osservatorio sull'internazionalizzazione delle imprese: Investimenti diretti esteri greenfield in Italia, 1998-2012.” Economia e Politica Industriale 41 (2): 99-111.

Mini, Peter. 1968. "Foreign Direct Investment in Italy, 1956-1963: Some Developmental Aspects." American Journal of Economics and Sociology 27 (1): 77-88.

Ministero di Agricoltura, Industria e Commercio. 1899. Annali del credito e della previdenza. Elenco generale delle società industriali nazionali ed estere costituite legalmente, ed autorizzate ad operare nel Regno al 31 dicembre 1897. Rome: Tipografia Nazionale G. Bertero.

Ministero delle Finanze. 1925-1926. "I capitali delle società straniere operanti in Italia." Bollettino di Statistica e di Legislazione Comparata II.

Monotti, Carlo. ed. 1975. I gruppi industriali in Italia. Turin: Valentino.

Mudambi, Ram, and Pietro Navarra. 2003a. Political culture and foreign direct investment: The case of Italy. Economics of Governance 4 (1): 37-56.

Mudambi, Ram, and Pietro Navarra. 2003b. "Political Tradition, Political Risk and Foreign Direct Investment in Italy." Management International Review 43 (3): 247-265.

Nitti, Francesco Saverio. 1915. Il capitale straniero in Italia. Bari: Laterza.

Onida, Fabrizio, ed. 2007. Le multinazionali estere in Lombardia e in Italia: opportunità, tendenze e prospettive. Milan: EGEA.

Onida, Fabrizio, Sergio Mariotti, and Lucia Piscitello. 2003. "Foreign Ownership: The case of Italy." CESPRI Working Paper 143, Milan.

von Oswald, Anne. 1994. "L'industria tedesca in Italia dall'età giolittiana alla seconda guerra mondiale." Archivi e imprese 10: 34-72.

Pantaleoni, Maffeo. 1914. "Non xenofobia ma autarchia". Il Giornale d'Italia, December 24th.

Pavan, Robert J. 1976. Strutture e strategie delle imprese italiane. Bologna: Il Mulino.

Pazienza, Pasquale, and Vincenzo Vecchione. 2009. "Preliminary investigation of the determinants of FDI distribution in Italy." Journal of Business Economics \& Management 10 (2): 99-107. 
Pells, Richard. 1997. Not Like Us: How Europeans Have Loved, Hated, and Transformed American Culture Since World War II. New York: Basic Books.

Pietrobelli, Carlo, Roberta Rabellotti, and Marco Sanfilippo. 2013. "What Drives Chinese Multinationals to Italy?" In Geography, Institutions and Regional Economic Performance, edited by Riccardo Crescenzi, 397-414. New York and Heidelberg: Springer.

Poettinger, Monika, 2007. "Imprenditori tedeschi nella Lombardia del primo Ottocento: spirito mercantile, capitale sociale ed industrializzazione." Rivista di Storia Economica 3: 319-360.

Preziosi, Giovanni. 1915. La Germania alla conquista dell'Italia. La finanza errante. Florence: Edizioni di AR.

Reganati, Filippo, and Edgardo Sica. 2007. "Horizontal and vertical spillovers from FDI: Evidence from panel data for the Italian manufacturing sector." Journal of Business Economics \& Management 8 (4): 259-266.

Ricerche e Progetti. Various years. Italia Multinazionale: le partecipazioni italiane all'estero ed estere in Italia. Milan: Edizioni del Sole 24 Ore.

Romeo, Rosario. 1988. Breve storia della grande industria in Italia. Milan: Mondadori.

Scott, Walter. 1960. Gli Investimenti Esteri in Italia. Analisi delle Partecipazioni Private Straniere in Società Italiane con Particolare Riferimento agli Investimenti Diretti (1946-1958). Milan: Feltrinelli.

Segreto, Luciano. 1985. "More trouble than profit: the investments of Vickers in Italy 1906-39." Business History 27: 316-37.

Segreto, Luciano. 1987. "Le nuove strutture delle società finanziarie svizzere per l'industria elettrica (1919-1939)" Studi Storici 37 (4): 860-908.

Segreto, Luciano. 1996. "Gli investimenti americani in Italia (1945-1963)” Studi Storici 37: 273-316.

Segreto, Luciano. 1995. "Reopening the Doors: U.S. Private Investments in Italy and the International Economic Integration Policy of the Italian Government, 1945-1965." Business and Economic History 24 (1): 231-242.

Solimene, Laura. 2000. "La SIV e l'industria del vetro piano: strategie di entrata e controllo della tecnologia”. Annali di Storia dell'Impresa 11: 475-526.

SORIS Research Centre. 1968. Effetti degli investimenti esteri in Italia. Milan: ETAS.

Tardivo, Giuseppe, and Rui Dias. 2003. Foreign direct investment models: Empirical evidence from Italy. Journal of Financial Management \& Analysis 16 (1): 36-52.

Toninelli, Pier Angelo. 2009. "Between Agnelli and Mussolini: Ford's Unsuccessful Attempt to Penetrate the Italian Auto-mobile Market in the inter-war period." Enterprise and Society 10 (2): 335-75. 


\section{Journal of Evolutionary Studies in Business}

Toniolo, Gianni. 1980. L'economia dell'Italia fascista. Roma-Bari: Laterza.

Toniolo Gianni. 1983. "L'utilizzazione dei fondi Erp nella ricostruzione italiana: alcune ipotesi di lavoro.” In Il Piano Marshall e l'Europa, edited by Elena Aga Rossi, 189-192. Rome: Istituto dell'Enciclopedia Italiana.

Toniolo, Gianni. 2013. “An overview of Italy's economic growth.” In The Oxford Handbook of the Italian economy since Unification, edited by Gianni Toniolo,3-36. New York: Oxford University Press.

Venturelli, Francesco, Marino Milone, and Antonio Pastore. 1979. Alcuni dati economico-finanziari relativi ad imprese multinazionali operanti nel Mezzogiorno. Bari: Cacucci Editore.

UNCTADSTAT. 2016. "Foreign direct investment: Inward and outward flows and stock, annual, 19802014." Accessed April 26, 2016. http://unctadstat.unctad.org/wds/TableViewer/tableView.aspx.

US Department of Commerce. 1930. American Direct Investments in Foreign Countries. Washington: US Gov. Printing Office, reprinted by Arno Press (1978).

Wilkins, Mira. 1970. The Emergence of Multinational Enterprise: American Business Abroad from the Colonial Era to 1914. Cambridge, MA: Harvard University Press.

Wilkins, Mira. 1974. The Maturing of Multinational Enterprise: American Business Abroad from 1914 to 1970. Cambridge, MA: Harvard University Press.

Zamagni, Vera. 1978. Industrializzazione e squilibri regionali in Italia. Bologna: Il Mulino.

Zamagni, Vera. 1990. Dalla periferia al centro. La seconda rinascita economica dell'Italia (18611990). Bologna: Il Mulino.

This is an Open Access article distributed under the terms of the Creative Commons Attribution-Non-Commercial-No Derivatives License (http://creativecommons.org/licenses/by-nc-nd/4.0/), which permits non-comercial re-use and distribution, provided the original work is properly cited, and is not altered or transformed in any way. 